\author{
The Politics of Liberalisation: \\ Privatisation and Regulation-for-Competition in \\ Europe's and Latin America's Telecoms and Electricity Industries \\ David Levi-Faur \\ Nuffield College \\ Oxford OX1 1NF, U.K.
}

Nuffield College Working Paper in Politics 2002-W13

A draft of this paper was presented at a workshop on National Regulatory Reforms, ECPR Joint Sessions, Grenoble, 6-11 2001, chaired by Adrienne Héritier and Mark Thatcher, the UADES/CARR workshop "The Europeanisation of National Economic Orders:", London School of Economics, 8 June 2001, chaired by Martin Lodge as well as in the seminar of the Centre for the Study of Globalization and Regionalisation, University of Warwick, 5th October 2001. I would like to thank the chairs and participants of these workshops and seminar as well as two anonymous referees of this journal for their helpful comments and suggestions. Prof. Jeremy Richardson who hosted and supported my research and a Marie Curie Fellowship made this research a feasible enterprise. 


\title{
The Politics of Liberalisation: Privatisation and Regulation-for-Competition in Europe's and Latin America's Telecoms and Electricity Industries
}

\begin{abstract}
$\underline{\text { Abstract }}$
This paper sheds some light on the interaction between politics and learning in the diffusion of liberalisation. It does so by specifying the conditions and ways in which politics and learning interact and thus sustain cross-national and cross-sectoral variations in the spread of liberalisation. The process of liberalisation is analysed against data from 32 European and Latin American countries and two sectors. The indicators employed cover the issue of privatisation as well as that of regulatory reforms. The paper presents an analytical framework that for the first time allows a systematic quantitative examination of the contrasting predictions of the Policy Sector Approach (PSA) and the National Patterns Approach (NPA). Four different combinations of variations and similarities across sectors and nations are identified and explained. The explanations for all four rest on actor-centred historical institutionalism. The empirical evidences point to the failure of Latin American to become 'European' despite the appearance of sweeping and comprehensive liberalisation. In addition it demonstrates how rational actors act in different institutional environments while accommodating the process of learning to their advantage and how their actions are constrained by different historical legacies of state formation and varied levels of risks and rewards inherent in different sectors.
\end{abstract}

Key Words: Regulatory Reforms, Privatisation, Liberalisation, Telecommunications, Electricity, Latin America, Europe. 


\section{The Politics of Liberalisation: \\ Privatisation and Regulation-for-Competition in Europe's and Latin America's Telecoms and Electricity Industries}

It is commonly said that the Latin American is more European than a Spaniard, because a Spaniard is a Spaniard before he is a European. And the same goes for a Frenchman, who is French before anything else, and the same goes for all the other peoples of Europe. Latin Americans see Europe from the outside, as a whole, and so they are able to be true members of the continent without even visiting it.

(Louis de Bernières, The Troublesome Offspring of Cardinal Guzman, p. 105)

Does politics determine learning or does learning determine politics? Some influential interpretations of the liberalisation of world economies seem to suggest, although rarely explicitly, that learning is the driving force behind the 'great transformation' to a more liberal world. We know better now, so the argument goes, and therefore replace the old public monopolies with new, efficient and profit-hungry corporations that can adapt better to the complex economic interactions and rapid technological changes of today. This newly-acquired knowledge and the harmonious working of markets and technologies are reflected in the irresistible diffusion of liberalisation across countries and sectors. This plausible argument - often advanced by economists - represents a theoretical challenge to political analysts since learning is often described and perceived as an apolitical process (cf. Hemerijck and van Kersbergen, 1999).

Some efforts to deal with this theoretical challenge were made in the literature in the last years. This is reflected via the popularisation of notions such as lesson-drawing (Rose, 1991), isomorphism (DiMaggio and Powell, 1991), growth of epistemic communities (Haas, 1992), policy harmonisation (Majone, 1991), policy emulation (Bennett, 1991) and policy learning (Sabatier and Jenkins-Smith, 1988), as well as the effort to model types of policy learning (Dolowitz and March, 2000). All these notions testify to the growing awareness in the profession of the importance of the politics of learning in making change desirable and possible. ${ }^{1}$ In order to deal with the theoretical challenge of the 'learning-determine-politics' approach this paper demonstrates how politics and learning interact in the diffusion of liberalisation across 
Europe and Latin America in the telecommunications and electricity sectors. In doing so, the paper also demonstrates how collective learning is a political process and how it mediates the process of learning. The analysis is grounded in the theoretical framework of actor-centred historical institutionalism. Thus cross-national and crosssectoral commonalties and variations are analysed as a product of cost-benefit calculations of actors constrained by the sectors they confront as well as by their institutional context - most significantly the power of the state and the relationship between state and society (Levi, 1988; Geddes, 1994; Hall and Taylor, 1996; Thelen and Steinmo, 1992; Scharpf, 1997). This theoretical framework is employed to account for the slower pace of liberalisation in electricity as compared to that of telecoms as well as to explain how Latin American liberalisation differs inherently from the European despite apparent similarities_between the two regions). It thus allows us to unfold the Latin American saga of continuity amid the struggle to create institutional structures strong enough to promote economic development and of the foiled effort to become European in more than a superficial sense.

Two important aspects of the process of liberalisation in the telecoms and electricity sectors are examined: Privatisation of ownership and the creation of regulatory structures for the promotion of competition, including the establishment of the socalled Independent Regulatory Agencies (IRAs). ${ }^{2}$ Whereas in the United States IRAs and private ownership have long been the dominant form of utilities' governance, most other countries have only recently adopted this form of governance (see Graphs 1\&2). The study of privatisation and IRAs promises not only to capture two of the most important aspects of liberalisation but also to furnish us with two complementary viewpoints on its patterns of diffusion. While it might be argued that privatisation is intimately connected with the retreat (selling, shrinking) of the state, the creation of IRAs might well serve as an indicator of restructure, which paradoxically - reinforces state control over the economy (Levi-Faur, 1998). This paper demonstrates how variations in state--society relations and especially in the strength and autonomy of the state, are responsible for subtle, but crucial, trajectories of liberalisation in Latin America and Europe across different sectors.

\section{Insert Graphs $1 \& 2$ about here}


The two sectors studied here - telecoms and electricity - were closely intertwined with the nation-state as we have come to know it since the late nineteenth century. The rise of big business, the welfare state, the mixed economy, and the affluent society of the post-war era are all mirrored in the development dynamics of these industries and especially in the acceleration of rural and urban electrification; impelling the process of telephonication; nationalisation; nurturing national equipment industries; and constructing nationally-bounded electricity and telephony networks. Since the early 1980s, however, remarkable changes are clearly evident. Notable in the telecoms field are the divestiture of AT\&T (1984) as well as the privatisation of British Telecom (1984) and Nippon Telegraph and Telephone (1985) (Newbery, 1999). ${ }^{3}$ In the 1990s privatisation and the establishment of Separate Regulatory Agencies (SRAs) became widespread across countries and sectors. Graph 1 presents the structural change affected in the governance of the telecoms industries since the mid-1980s. In 113 countries world-wide the Ministries of Telecommunications and Post relinquished at least part of their regulatory powers to SRAs bearing significant technological and economic orientation. The promotion of competition through a blend of regulation and deregulation was widely practised. Notable was the targeting of long-distance and local telecoms services and the development of a regulatory framework for the European Union with directives on open networks (1990) and on interconnection (1997) (Natalicchi, 2001).

Similarly to the changes in telecoms though less markedly, indications of change are evident in the electricity industry. The first indication of systematic change was probably that of former US President Jimmy Carter in his Public Utilities Regulatory Policies Act (1978). This act opened electricity generation to independent power producers. Remarkable were the divestiture and privatisation programs of Chile (1979-1986) and even more so the divestiture and privatisation of the British electricity industry (1989-1995). While indications of change seemed sporadic in the 1980s, by the mid-1990s, it became clear that the world electricity industry was facing a tremendous transformation (Gilbert and Kahn, 1996; Pollitt, 1997). Indeed, a significant development was the EU's electricity directive of 1996 (Schmidt, 1997). In electricity as in telecoms privatisation and the establishment of SRAs became widespread. Graph 2 presents the advance of SRAs in the electricity industry. In 57 out of 130 countries where data was available SRAs now regulate the sector. 
Our analysis of the politics of liberalisation of telecoms and electricity is grounded in a systematic collection of data from 32 countries (see Appendix A). Only four Latin America's Costa Rica, Ecuador, Paraguay and Uruguay — did not privatise either of the two industries. In 16 countries out of the 32 studied there is evidence of full or partial privatisation of both sectors. Partial or full privatisation had occurred in 44 out of 63 possible cases in both sectors. ${ }^{4}$ Telecoms and electricity authorities that were in 1975 largely under public ownership are now either of mixed ownership (electricity) or of mostly private ownership (telecoms). Similarly, in the field of regulation, all countries established SRAs in either the telecoms or the electricity spheres. SRAs were established in 56 cases out of a possible 64. Graphs 1 and 2 demonstrate an extremely rapid pace of change. From a very modest start in the mid1980s, the establishment of SRAs around the world became normal practice in the mid-1990s. The pace is so rapid and its spread so comprehensive that it is reasonably safe to predict that most countries are bound to privatise and establish SRAs for these industries in the near future.

The paper explains both commonalties and variations across nations and sectors and in doing so reconciles the Policy Sector Approach (PSA) and the National Patterns Approach (NPA) (Atkinson and Coleman, 1989; Hollingsworth, Schmitter and Streeck, 1994; Waarden, 1995). These approaches call for different levels of analysis and consequently offer different predictions on the mechanisms that carry and propel the spread of liberalisation. The analytical framework recognises the importance of both in a way that allows it to explore the conditions under which each provides a more persuasive explanation. Specifically, four combinations of variations and similarities across sectors and nations are here identified and explained. First, similarities across nations and sectors are explained as the outcome of the cost-benefit calculations of public officials' perceiving liberalisation in terms of policy learning. Jumping on the liberalisation bandwagon reflects their 'desire' to learn but also political calculations of risk-and-cost of lagging behind. This explanation sheds some light on the political aspects of learning which undermine the strong apolitical reasoning seemingly behind (some explanations of) the process of diffusion of liberalisation. Second, variations in public actors' strategies in two different institutional settings - strong states versus weak states - explain cross-national 
variations that serve as evidence of the NPA. Specifically, it is argued that strong states tend to learn more than to emulate, to embrace voluntary transfers rather than coercive ones, and to adopt complex rather than simple types of policies. Third, crosssectoral variations supporting the PSA are explained as the outcome of the different risks-and-rewards that the two sectors represent for public officials. Higher risks in electricity and greater political and economic rewards in telecoms explain the greater propensity of public officials to liberalise telecoms. Finally, variations across both nations and sectors are identified. Specifically, that the PSA is supported mostly by the European cases, while the NPA is supported by Latin American cases. This pattern is the outcome of the differences in the demand and supply of social support between Europe and Latin America.

\section{Analytical Framework}

As of the late 1980 and increasingly since the mid-1990s, privatisation and IRAs gained ground and have become widespread in electricity and telecoms. ${ }^{5}$ Liberalisation started in the 1980s with an emphasis on 'privatisation', but in the 1990s attention seemed to shift to regulatory reforms, in particular to the promotion of competition in the infrastructure of capitalist economies (Newbery, 1999). One of the indications for these developments is reflected in the literature on the rise of the regulatory state appearing since the late 1980s (e.g., Veljanovski, 1987; Majone, 1990; Moran, 2001; Muller, 2002). While privatisation policies are centred on the form of ownership and specifically on the transfer of ownership from public to private domain, regulatory reforms are centred on the creation of institutional and regulatory rules and incentives for the promotion of competition. This entails rules for each segment of the network fashioned according to its perceived potential for competition on the one hand and the balance of power between actors and institutions on the other (Levi-Faur, 1999). This design of competition rules requires legal and administrative capacities and extensive technological and economic experience and knowledge. Thus, if privatisation signifies a retreat of the state, regulation-of-competition represents the return of the state. Together they reveal the Janus head of liberalisation and the paradox of "Freer Markets, More Rules" (Vogel, 1996). 
Liberalisation appeared on the public agenda as an ideology of economic freedom and political liberty. Yet normative arguments were always supported by a variety of efficiency-driven arguments such as the perceived failure, or at best mediocrity, of government enterprises as compared to private entrepreneurship. The problems of principal-agent relations, capture, accountability, and managerial autonomy vs. political interference and motivation that are often associated with public ownership were often used to justify privatisation (Vickers and Yarrow, 1988; Hodge, 2000). A measure of the success of this double-edged advocacy of privatisation is found in notions of 'paradigm change' (Hall, 1989) and 'hegemony breakdown' (Kalyvas, 1994) that became popular in the discourse of modern political and economic changes. Yet liberalisation was manifested in more ways than privatisation, not least in the creation of new regulatory agencies. Unlike privatisation, SRAs were not a salient feature of the programmatic change probably because the establishment of new state agencies somewhat contradicted the ideology of 'free markets'. IRAs are portrayed as less vulnerable to problems that plague government ministries, such as political pressures, civil service wage-scale constraints and limited public budgets. IRAs are designed as small, professional units and are - due to financial independence and transparent design - less prone to capture (Cukierman, 1992; Levy and Spiller, 1996; Doren and Wilks, 1998). In industries that require long-term investment, above all infrastructural industries, IRAs offer prospective investors the security of a stable investment climate and predictable rules, as are essential in attracting large-scale capital investment at minimum cost.

There are at least five good reasons that support the view that liberalisation reflects 'policy learning'. The first and possibly most important is that the magnitude of change is so great that it is inconceivable to attribute it to the capacity of any one actor. One needs to introduce an omnipotent actor to the analysis of political change in order to argue that it reflects power and interests rather than knowledge-induced choice (even if this choice reflects adaptation to external pressure). Second, the proximity in the timing of the reforms across countries and sectors supports the plausibility of this view. Again, the power-centred approach would require an omnipotent actor to explain the simultaneous occurrence of reforms across different countries and sectors. Third, the spread of liberalisation is characterised by minimal international conflict. Pressures from the World Bank, the International Monetary 
Fund, the US Government and the European Commission are clearly evident but do not necessarily contradict the notion of learning. As liberalisation involves domestic political costs it actually helps to have these balanced by pressure from international creditors. Moreover, professional communities, notably economists, advocating liberalisation as a source of efficiency, increase the plausibility of the "learning determine politics' approach. Fourth, there are distinct technological innovations mainly digitalisation and compression - that might be used to lower the transaction costs of private ownership of these industries. To the extent that state officials can utilize these innovations and redesign governance structures, one may reasonably suggest that the process is knowledge-driven. Finally, the mixture of regulatory reforms and privatisation in the process of liberalisation reflects a balanced approach to the notion of political control over business. True, privatisation is clearly beneficial to business and in the case of telecoms and electricity especially to business in developed economies but the creation of SRAs is much less so. It is important to note that while each of these five factors is contestable and one may well argue that liberalisation was cognitively constructed (or manipulated) as a learning process. The plausibility of these argument is not a subject matter of this paper. Instead it suggests that the 'learning determine politics approach' enjoys most favourable conditions in the case of telecoms and electricity liberalisation. On this background our efforts to identify the political aspects in the spread of liberalisation are especially important if one is interested to establish the case for the opposite approach.

\section{Insert Table 1 about Here}

In order to capture and then explain the complex picture of the spread of liberalisation and the interaction between learning and politics, we have employed a fourfold distinction between possible outcomes of the spread of liberalisation (see Table 1). The Policy Sector Approach (PSA) suggests that the sectors are bound to exhibit similar patterns across countries. Thus policy-making is likely to converge across sectors in different countries (Atkinson and Coleman, 1989; Hollingsworth, Schmitter and Streeck, 1994). The National Patterns Approach (NPA), by contrast, predicts that the major variations will be among nations, not across sectors (Richardson, 1982; Vogel, 1986). These conflicting predictions on the extent of similarities and variations 
across nations and sectors are summarised in Table 1. Four combinations of evidence are possible, each leading to a different conclusion. First, the PSA will be confirmed to the extent that cross-national similarities and cross-sectoral variations are identified. Second, the NPA will be confirmed to the extent that cross-sectoral similarities and cross-national variations prevail. Third, evidence of similarities across both sectors and nations implies the existence of extra-national and extra-sectoral forces, probably global, which affect the governance regimes of all sectors and nations. The solution here is to move to the global level of analysis and acquire tools of investigation, which are more in tune with international factors than with comparative politics and comparative public policy. Finally, evidence of both crosssectoral and cross-national variations requires an answer as to when and why one of approaches is more useful than the other.

\section{Research Design}

Most studies of regulatory reforms and especially the study of the liberalisation of the world's infrastructure are grounded often in one or more of the following three research strategies. First, on small-N analysis, that is, including one to four cases. Second, on sector-specific study, that is, on the study of one specific sector often in one to four countries (e.g, telecoms in Britain and France). Third, on Most Similar System Design, that is, on the selection of cases so as to minimise the effect of political and economic variations. In Most Similar System Design the logic of comparison is based on the assumption that the more similar the cases being compared, the simpler it should be to isolate the intervening factors (Przeworski and Teune, 1970). An alternative approach - usually associated with statistical analysis is to select the case on the principle of a Most Different System Design. Here the logic is to compare as different cases as possible, demonstrating the robustness of a relationship between dependent and independent variables. Such a design assumes that the argument of the research is better supported by demonstrating that the observed relationship holds despite the wide range of contrasting settings (Ibid.). This paper extends the research in the fields of comparative public policy and comparative political economy in that it offers a research design that may best be characterised as Medium-N analysis employing both Most-Similar and Most-Different designs, combining analyses at both the sectoral and the national levels. 
While it is frequently recognised that liberalisation and regulatory reforms are mediated by sectoral and national variables (most recently by Henry and Matheu, 2001: 21-23), I am unaware of attempts to capture the relative importance of these variables via quantitative research designs. The move toward the inclusion of 64 cases of liberalisation (32 countries times 2 sectors) represents therefore some progress, not least because it differs from the common practice in case-oriented studies. The cases are aggregated to present trends across sectors and nations and allow the use of descriptive statistics on the one hand and probabilistic analysis of causation on the other. The selection of countries follows the Most-Different Research Design as it includes countries from distinctly different regions of the world and specifically countries characterised by strong variations in the power of the state. The selection of countries thus represents a most-favourable design for the NPA, balanced by the vigorous convergence of liberalisation across nations. While the selection of countries is most favourable for the NPA, the selection of the indicators of liberalisation - privatisation and regulatory agencies - presents a most-difficult case. Unlike the selection of countries that follows the Most-Different design and therefore maximises the variations among the cases, the selection of the sectors follows the logic of most-similar design. The PSA that emphasises variations across sectors is confronted with the most similar cases of telecoms and electricity networks (Levi-Faur, 2000) and thus with the most challenging cases for its predictions. All in all, this somewhat unconventional research design can be interpreted as an effort to develop a methodology that will combine the strength of case-oriented analysis with quantitative approach. ${ }^{6}$

Two major studies by Eric Nordlinger, The Autonomy of the Democratic State (1981) and Taking the State Seriously (1987), serve to conceptualise the strength of the state. Following Nordlinger, we hold the state to be 'all the individuals who occupy offices that authorise them and them alone, to make and apply decisions that are binding upon any and all segments of society' (Nordlinger, 1981: 11). Nordlinger's distinction between types of states is followed although only two of his extreme types are used here. The strength of the state is determined by how it ranks on two variables: autonomy and societal support. Strong states are those that enjoy high autonomy and support while weak states rank low both on autonomy and support (Nordlinger, 1987: 
369). The state is autonomous according to Nordlinger 'to the extent that it translates its own preferences into authoritative actions. A totally autonomous state, if there is such an entity, invariably acts as it chooses to act, and does not act when it prefers not to do so....' (Nordlinger,1987: 362).

The strength of the state is operationalized as a dichotomous variable that takes the values 'weak' or 'strong'. It is assumed to be low for all Latin American cases and high for all European cases. This somewhat arbitrary classification is based on two foundations. First, it is based on extensive and largely uncontested qualitative literature on warfare and state building. The unique experience of warfare in Europe is suggested as the causal mechanism that has contributed to the creation of strong states in this region. As was argued by Tilly "war made the state and the state made war" (Tilly, 1975: 42). Stein Rokkan wrote that: 'the European sequence simply cannot be repeated in the newest nations' (Rokkan,1975: 600). It is therefore not surprising to find agreement in the discipline well beyond theoretical divisions that Latin American states are weak or dependent (Huntington, 1968: 1-2; Anglade and Fortin, 1985: 287; Migdal, 1988; Whitehead, 1994; Cardoso and Faletto, 1979; Fishlow, 1990). The weakness is to some extent the product of comparatively low levels of warfare during critical periods of state formation and of a lengthy period of Spanish and Portuguese patrimonial rule. Both the Spanish and the Portuguese, unlike the English, were hostile to the creation of corps intermédiaires in their polities, at home and abroad. Yet the most visible aspect of the weakness of the Latin American states is the limited degree of social support that they offered. A succession of political projects in Latin America - the oligarchic state, the populist state and the bureaucratic-authoritarian state - were strongly characterised by the absence of legitimacy and social control (Lewis, 2001).

The second justification for our decision to treat all Latin American as weak and all European states as strong is based on quantitative studies that assess the effectiveness of governance across nations. Various quantitative measures are offered to measure the strength of the state across nations. One of the recent and most extensive attempts was carried out by the World Bank's study group on governance (Kaufmann, Kraay and Zoido-Lobaton, 1999a, 1999b). They constructed a new governance database containing over 300 governance measures compiled from a variety of surveys, which 
were then aggregated to higher-level indicators. One of these indicators is the capacity of the government to effectively formulate and implement sound policies. ${ }^{7}$ The ranking for state effectiveness of each of the 32 countries included was calculated, as were averages and means for Latin America and Europe. Latin America achieved an average score of 50 points and a mean of 46 points; Europe achieved an average of 90 points with a mean of 93 points. While one may be sceptical about the theoretical value and accuracy of these measures, they seem to provide a fair indication (not least because they are also supported by the qualitative literature) of qualitative differences between the strength of the states in the two regions. ${ }^{8}$

Unlike the Latin American countries, fourteen of the sixteen European countries studied here liberalised their industries in the context of the EU policy process. This may raise doubts as to the validity of a cross-national comparison as there are clear interdependencies between the members of the EU. ${ }^{9}$ Yet the practical implications of Europeanization as an independent variable are rather limited. Despite the strong claims that the EU and especially the European Commission were critical factors in the diffusion of liberalisation in Europe the data on the spread of liberalisation in Europe does not support this view (Levi-Faur, 2002b). Most important is the fact that EU directives on telecoms and electricity are neutral with regard to privatisation and do not oblige member states to create SRAs or IRAs. ${ }^{10}$ Moreover, there are clear indications on the aggregate levels of national level preferences for liberalisation before the creation of the EU's telecoms and electricity regimes. To the extent that the EU policy process is an intervening variable - for example with regard to issues of access to networks - its effects on the decision whether or not to liberalise seem to be limited. Our data clearly shows that EU membership is not a necessary condition for liberalisation and that it also does not guarantee a more rapid move towards liberalisation. Many member states liberalised unilaterally and many countries outside the EU took similar steps without any 'supranational' commitments.

\section{Let the Data Speak: Variations and Similarities across Sectors and Nations}

Table 2 displays the aggregate data on the spread of liberalisation (see Appendix A for the raw data). The data is sliced according to various criteria. The first three columns present the data for all 32 countries studied. Column 1 aggregates the data 
for both the telecoms and electricity sectors; column 2 does so for telecoms and column 3 for electricity. The next three columns present the Latin American data while the final three present the data for Europe. Together they provide us with the opportunity to examine patterns of similarities and variations across countries and sectors.

\section{Insert table 2 about here}

Let us start with evidence of cross-national and cross-sectoral similarities (as summarised in column 1 of Table 2). First, it reveals the remarkable spread of the privatisation of incumbents in the electricity and telecoms sectors. In 44 out of 63 possible cases we found some form of privatisation. ${ }^{11}$ Second, the creation of separate regulatory agencies is another sweeping phenomenon. In 56 out of 64 possible cases, governments moved toward the establishment of separate regulators for the telecoms and the electricity industries. Third, similarities are evident for both sectors in both the median year for privatisation and the year of creation of SRAs (1995 or 1996 for both indicators). The fact that the median year is very similar is highly suggestive of the interdependence of privatisation across sectors and of the relations between privatisation and the creation of separate regulatory agencies. A fourth indication of similarities is the impressive number of agencies that are nominally autonomous from the government (38 IRAs). These cross-national and cross-sectoral similarities imply a process of change that seems to be driven by extra-sectoral and extra-national forces. It is therefore reasonable to assume that most of the remaining public telecoms and electricity incumbents are bound to be privatised in the coming decade.

A review of columns 2 and 3 of Table 2 reveals that four cross-sectoral variations support the PSA. First, the propensity of the telecoms sector to privatisation is found to be greater than that of electricity. Second, differences in the structure of ownership of the two sectors are still unmistakable. In 2000 telecoms and electricity showed corresponding scores of 3.4 and 2.8 implying that telecoms that was before the upsurge of liberalisation was markedly more 'public' than electricity is nowadays more 'private' than electricity. Not only do states tend to sell less of their electricity industries, but even when they do they tend to be more cautious in the measure of transfer of ownership. Third, there are significant variations in the number of SRAs 
across the sectors: 32 in telecoms but only 25 in electricity. Finally, there are significant variations in the extent of independence granted to the SRAs in these sectors (21 IRAs in telecoms versus 16 in electricity).

Comparison of the data in columns 4 and 7 (Table 2) allows us to examine the predictions of the NPA predictions. According to the NPA one should expect considerable variations across nations; since the Latin American and European groups are characterised by radically different state structures one should expect them to vary in their propensity to liberalisation. Support for these predictions comes initially from the larger number of privatisation events in Europe as compared to Latin America (24 and 20 respectively). Moreover, it seems that European and Latin American countries differ remarkably in the extent of their willingness to grant independence to their SRAs. Among the 27 SRAs in Latin America, merely 13 were designed nominally as independent. In Europe, by contrast, the ratio is 25 out of 29.

Columns 5, 6, 7 and 8 reveal that there are some systematic patterns in the support granted to the NPA and the PSA. While cross-national variations are more robust in the Latin American cases, cross-sectoral variations are more robust in the European cases. A first indication for such a systematic variation is evident from the number of privatisation events in Latin America and in Europe. While the number of events in the Latin American countries is similar for both sectors, there is considerable difference in the European countries (16 events in telecoms but only 8 in electricity). Second, there are variations in the median years in telecoms and electricity privatisations across Europe (1996 and 1991 respectively) but no significant variation across Latin America (1994 and 1995 respectively). Third, there is significant variation in the median year for the establishment of separate regulatory agencies for telecoms and electricity across Europe (1993 and 1996 respectively) but much less so across Latin American (1995 and 1994 respectively). Finally, there are significant variations in the extent of independence granted to IRAs across Europe for telecoms and electricity (15 and 10 respectively) but not across Latin America (6 and 7 respectively).

The findings, as summarised in Table 2, show evidence of systematic variations and commonalities across nations and sectors. Yet, surprisingly enough, the NPA 
received rather limited support from the indicators that are considered in Appendix A. This raises the question (and for some probably the hope) have Latin American countries finally closed the gap with Europe? Could it be that in the future, novelists will need to find new targets for their ironic attitude towards political and economic development Latin America?. In what follow we would like to warn the reader from such an hasty conclusion. We do that not on the basis of economic outcomes such as tariffs and access for telephony but on the basis of the patterns of diffusion. Let us analyse the data as to the support for the NPA. The support comes mainly from the variations in the number of IRAs across the two regions and to a more limited extent from the variations in the number of privatisation events. ${ }^{12}$ This indicates considerable convergence across regions. Yet the sweeping force of liberalisation renders it a rather difficult case for the NPA. This limited support is puzzling in view of the fact that the selection of nations followed a favourable case design (maximising variations so as to include weak and strong states, economically developed and underdeveloped).$^{13}$ One way to deal with this limited support is to argue that liberalisation is a very difficult case for the NPA and that therefore even the limited extent of variations is impressive. This suggestion, though reasonable, does not convey any qualitative assertion on the effects of national level variables on liberalisation. Thus, in order to do more than to defend the NPA and establish a stronger case for divergence processes in Europe and Latin America, the subsequent part of the paper analyses indicators of how countries liberalised rather than on whether they did so.

\section{In Search of National Variations}

Appendix B presents a complementary set of data on the liberalisation process in the two sectors and in the 32 Latin American and European countries. The data presented includes the style of privatisation, namely, its extent (whether partial or full), as well as the extent of regulatory reforms in three different segments of the sectors. These indicators reflect the current situation of global convergence on liberalisation. Since all (or almost all) countries privatise and create SRAs, the effects of national variables would be more salient in the implementation stages of the policy process than in the decision-making stages. In order to make sense of the differences the following three indices of the transfer of liberalisation have been constructed. 
The Learning Transfer Index (LTI) offers some indirect indication of the extent of emulation as opposed to learning in the spread of liberalisation. The distinction between emulation and learning captures the depth of considerations and seriousness of commitment in introducing policy changes. While emulation involves imitating action that occurs elsewhere, learning involves a redefinition of one's interests on the basis of newly-acquired knowledge (Ikenberry, 1990: 88). The index is composed of two indicators. While one reflects the decision to privatise, the other reflects the decision to create an SRA or IRA. The extra weight for the regulatory agency indicator reflects the recognition that the critical part of the liberalisation program is evident in promotion of competition rather than in transfer of ownership. It is noteworthy that while this paper considers privatisation and independent regulatory agencies as products of learning, this does not imply that they reflect any kind of higher and absolutely better form of political control. They are perceived as a new form of rationalisation that is supported by historically bounded professional knowledge. In other words, they represent policy learning as long as the actors in the policy process perceived them to be so. In addition, like the other two indices, the LTI should serve to establish relative levels of learning versus emulation in policy transfer, rather than an absolute level of emulation or learning. Thus, while the index may point to higher levels of learning in Europe, it does not imply that Latin America does not learn or that Europe does not emulate.

$$
\begin{aligned}
& \mathbf{L T I}=\sum_{1}^{n} \mathrm{PRV}_{\text {telecom }}+\mathrm{PRV}_{\text {elect }}+2\left(\mathrm{RA}_{\text {telecom }}+\mathrm{RA}_{\text {elect }}\right) \\
& \mathbf{L T I}_{\text {LatinAmerica }}=60 \quad \mathbf{L T I}_{\text {Europe }}=78
\end{aligned}
$$

\section{LTI Key:}

$\mathrm{PRV}=$ Privatisation $(\mathrm{Yes}=1, \quad \mathrm{No}=0) ; \mathrm{RA}=$ Regulatory Authority (Independent $=1$, Separate $=0.5, \mathrm{No}=0$ ).

The Voluntary Transfer Index (VTI) indicates the relative prevalence of voluntarism (that is, autonomously relying on one's own preferences) and coercion in the spread of liberalisation across nations. The index is composed of two indicators. The first reflects the style of privatisation by distinguishing between full-scale privatisation and 
partial privatisation. Partial privatisation was defined as the sale of a minority rather than a majority of the shares of the state in telecoms and electricity operators. The style of privatisation would be considered partial even if the government moved at a later stage (but not less than two years after the initial action) to privatise the whole company. All other acts of privatisation were considered full privatisation. By assigning one point to partial privatisation and zero to full privatisation the index reflects the degree of emergency and therefore coercion in the decision to privatise. The second indicator measures the difference in the timing of privatisation between telecoms and electricity. This indicator assumes that voluntarism in policy transfer is reflected in longer time spans in the decision to privatise the two sectors. Simultaneous privatisation of both sectors reflects external pressure - financial or political - to sell immediately and without the benefit of experimentalism.

$$
\begin{gathered}
\text { VTI }=\sum_{1}^{n} \mathrm{PP}_{\text {telecom }}+\mathrm{PP}_{\text {elec }}+\left|\mathrm{YP}_{\text {telecom }}-\mathrm{YP}_{\text {elec }}\right| \\
\mathbf{V T I}_{\text {LatinAmerica }}=82.5 \quad \mathbf{V T I}_{\text {Europe }}=148 \\
\underline{\text { VTI Key }} \mathrm{PP}=\text { Partial Privatisation }(\mathrm{Yes}=1, \mathrm{No}=0), \mathrm{YP}=\text { Year Privatisation }
\end{gathered}
$$

Finally, the Complexity of Transfer Index (CTI) is composed of weighted measures of three different indicators. These indicators were devised to capture the extent of administrative complexity that is involved in regulation for competition in each of the sectors. Some policies are more difficult to adopt than others. Usually the costs arise in the implementation stage but state officials are often able to anticipate difficulties in that process and thus their decisions may be affected by their perceptions of the costs of implementation. ${ }^{14}$ The scale was devised to reflect the extent to which policies externalise or internalise administrative costs for the state. The administrative costs of a policy are externalised when the costs of implementation fall mainly or solely on actors outside the state machine. They are internalised when the implementation of policy requires considerable state resources. By using these criteria it is possible to distinguish between the most simple policies that externalised administrative costs, such as long-distance competition in telecoms and divestiture in 
electricity, and the most complex policies, namely, unbundling the local loop in telecoms and retail competition in electricity. An intermediary case of complexity is that of the interconnection regimes in telecoms and open access for transmission networks in electricity.

$$
\begin{array}{r}
\mathbf{C T I}=\sum_{1}^{n} \mathrm{INT}_{\text {telecom }}+\mathrm{DIV}_{\text {elec }}+2\left(\mathrm{IN}_{\text {telecom }}+\mathrm{OA}_{\text {elec }}\right)+3\left(\mathrm{UB}_{\text {telecom }}+\mathrm{RC}_{\text {elec }}\right) \\
\text { CTI }_{\text {Latin America: }}: 60 \quad \text { CTI }_{\text {Europe }}: 145.5
\end{array}
$$

\section{CTI Key and note:}

$\mathrm{INT}=$ international competition, $\mathrm{DIV}=$ divestiture, $\mathrm{IN}=$ interconnection, $\mathrm{OA}=$ pen access to the transmission networks; $\mathrm{UB}=$ unbundling, $\mathrm{RC}=$ retail competition

Partial competition and partial divestiture were given scores of 0.5 for the calculation of the Complexity of Transfer Index (CTI). Other indicators were scored 1 for Yes, RTPA, or NTPA. No was scored 0 .. While the easiest aspects, long-distance competition and divestiture, were graded by 1 point, unbundling the local loop and retail electricity competition were graded at 3 points per positive case. The intermediary aspects of the creation of telecoms interconnection regimes and open access regimes for the transmission networks were graded 2 points for each positive case.

All in all, when compared with Latin America, the liberalisation of European telecoms and electricity industries is characterised by greater measures of learning, voluntarism and complexity. In all three indexes the European countries score better than the Latin American. The extent of variations inside the Latin American and European groups was minimal, suggesting that what has been captured here is significant national variations rather than regional ones. These findings reinforce the validity of the NPA and reveal the divergencies in the patterns of liberalisation in Europe and Latin America.

\section{Actors, Institutions and Policy Transfers: Games Real Actors Play}

This section offers explanations for the patterns of similarities and variations across the countries and the sectors studied. The analysis tackles the four different situations that we defined from the political and economic viewpoint of state officials who are at 
the intersection between the domestic and the international domains. The relevant external environment includes institutions such as the World Bank and the European Commission as well as all-powerful and affluent governments such as the United States (with direct and indirect control over huge financial resources) and Britain (often the best-practice model but even more often the reference point for selfevaluation by non-Britons). The domestic environment includes the electorate, epistemic communities and special interest groups, particularly business and labour. When liberalisation appears as a policy option on their agenda, state officials undertake cost-benefit analyses. In a strife to balance policy success and political survival, liberalisation is considered not only on its merits but also as an instrument of political survival.

\section{Explaining General Patterns}

Why similarities across both sectors and nations? The rapid advance of liberalisation across sectors and nations alludes to some strong incentives to liberalise and possibly to some constraints on retaining the status quo as well. Actor-centred analysis may suggest that liberalisation is a special case wherein conflicts between politicians' survival and success games were minimal. One may go even farther and say that these goals were interdependent, as the first could not be achieved without the second. Given the strong role of learning in the spread of liberalisation, one needs to explain not the move toward liberalisation but rather the convergence of the survival and success games. How come that the personal survival of public officials and their perception of what is best for their societies mutually support each other? Two complementary answers stand out. First, to the extent that state officials are riskaverse and survival-oriented, a plausible strategy for minimising vulnerability is to conform to dominant forms of behaviour. Second, state officials are social actors and consequently tend to conform to group pressures and political fashions. In both cases a framework of analysis that combines 'herd theories' from the field of economics (Bikhchandani, Hirshleifer and Welch, 1992), threshold theories of collective action (Granovetter, 1978), and diffusion theories (Rogers, 1983) might prove useful in the effort to explicate the mechanism of convergence of large groups of policy-makers on similar policy choices (Levi-Faur, 2002a). When many policy-makers converge on a similar policy choice, such as in the case of liberalisation, that policy becomes a new convention. ${ }^{15}$ Conventions create strong norms and consequently opportunist 
strategies, such as foot-dragging and fence-sitting, are rather limited. As privatisation and the creation of regulatory authorities became major facets of change, public officials found them difficult to resist even if this implied conflict with incumbents and labour unions. Extra-national and extra-sectoral institutions served as discount mechanisms for liberalisation. The European Commission in the European cases and the World Bank, the IMF and the United States governments in the Latin American cases supplied legal, financial and ideational incentives for liberalisation. At the same time, they served as useful targets for blame-shifting for state officials facing domestic opposition.

Two issues should be clarified before we move on to a discussion of other aspects of the transfer of liberalisation. First, these explanations do not offer a rationale for the starting point of the process. If state officials are risk-averse and susceptible to social fashions, how could one account for the first few cases of liberalisation that are definitely risky? Here, contextual explanations such as the ideological leaning of visionaries in Britain and in Chile may be mobilised. This may provide a more comprehensive picture of the transfer of liberalisation but it weakens the analytical rigor of our concept of risk-averse and socially-conforming actors. Second, the explanation does not rely on institutions or institutional variations in accounting for the similarities. The forces that shape the similarities across nations and sectors act in a monotonic way across institutional settings. Institutions are found to be much more useful when variations are considered.

\section{Explaining Cross-Sectoral Variations}

Support for the PSA is manifested in the greater propensity of telecoms for privatisation and the establishment of SRAs and IRAs. As public officials are riskaverse and vote-maximizers across sectors, it is possible to explain cross-sectoral variations in liberalisation by reference to the variations in risks-and-rewards that the two sectors represent. In what follows I intend to demonstrate that for both economic and technological reasons liberalisation of electricity is less rewarding and more risky than the liberalisation of telecoms.

Five major factors are responsible for the higher political risks associated with electricity liberalisation. First, the gradual approach that allowed consensus-building 
in telecoms could be only partly applied to electricity. The liberalisation of telecoms first emerged in relatively small segments of the market and it took 15 year till it had extended to the local loop (that is, to the retail competition in the supply of local telephone services). This gradual process was only partly possible in electricity and thus consensus-building in this sector is more costly. The promotion of competitive markets in all segments of the electricity sectors had to be introduced simultaneously since they were closely interdependent. ${ }^{16}$ Second, experimentation with competition was only barely possible in electricity. Whereas it was possible to introduce competition to segments of the markets in telecoms (equipment, international and long-distance calls, mobile) and thus to experiment with competitive markets, the possibility of doing so in electricity was limited. Telecoms liberalisation was no doubt less risky than that of electricity.

A third reason for the higher risks of the liberalisation of electricity are the considerable costs involved in terms of levelling the field for new and old players. While entry of new suppliers is supported by innovative and efficient technologies of generation, the old integrated monopolies use less efficient methods such as nuclear energy and coal. Fair competition may mean that the incumbents be bailed out at a huge expense. ${ }^{17}$ Compensating the incumbents, whether private or public, is a costly measure both politically and financially. Fourth, electricity liberalisation calls for state officials to relinquish some of their control over their nation's 'energy mix', ${ }^{18}$ implying, for some states, a considerable increase in the extent of their energy dependency. Given the status of electricity as an essential service, national sensitivities over the control of the system, although gradually declining, are still strong enough to render reorganisation of the sector far more risky than the case with telecoms. Finally, system reliability is more critical in electricity as system failure may in the extreme cases involve loss of life and social and economic chaos. Although liberalisation does not necessarily lead to failure, it involves some problems of control during the transition periods that make it risky for state officials. All these reasons combined to render competition and the lessening of central control in electricity much more complex than with telecoms. The failure of the competitive regime in the electricity market in California had no equivalent in telecoms and may prove strong support for these assertions. 
Telecoms liberalisation is no doubt more rewarding for state officials, politically and economically. To some extent, public officials' agenda is geared toward solving the most urgent issues. To that extent, telecoms liberalisation reflects their calculations that not only are the costs of electricity liberalisation higher but its benefits are lower than those of telecoms. While both telecoms and electricity are sources of competitive advantage for national economies, telecoms services are critical for the most dynamic segments of the business community -- the information economy. State officials' attitudes to liberalisation were also affected by the recognition that the extent of social support for liberalisation of telecoms was wider than for electricity. It was therefore more rewarding for them to commit themselves to telecoms liberalisation. Moreover, electricity competition, even if successful in reducing tariffs, would affect household bills only marginally. But most important is that telecoms liberalisation has acquired a special status in the political and social perceptions of large and important segments of the public. Telecoms technologies are commonly perceived as 'technologies of freedom' and represent the more positive aspects of the dynamics of global, economic, and political change (Pool, 1983). The contemporary popular notions of 'information society' and 'information economy' are not natural representations of future social and economic trends. They are among the 'politics of symbols' which have shaped our perceptions of the good and the bad, the possible and the inevitable. If electricity technology is identified in our minds with large, polluting, mysterious, and dangerous generation technologies, telecoms technologies are identified with the digital telephone, the fax, the modem, and more recently the Internet: all common household gadgets. The opening of new venues in telecoms has become popular with the elites and the wider public alike, whereas such support is lacking in electricity. To the extent that state officials are vote- and legitimacy-maximizers, they have greater incentives to associate themselves with telecoms liberalisation than with that of electricity.

\section{Explaining Cross National Variations}

Support for the NPA is manifested in the greater propensity of Europe than of Latin America to create SRAs and IRAs as well as to learning and to voluntary and complex transfers. In order to explain these variations consider the variations in the cost-benefit considerations of public officials in weak vs. strong states. 
Public officials may initiate a process of learning or settle on emulation. Emulation has several advantages: it is less resource-demanding than learning, quicker in terms of results, more certain with regard to outputs, less dependent on external resources, and can freely concentrate on the aspects that acquire most support from mass media and international audiences. In view of the high costs of learning, the relative scarcity of professional input as well as the greater uncertainty of success, it is reasonable to suggest that public officials in a weak state will be more likely to emulate than their counterparts in a strong state. The LTI supplies some support for this proposition as it points to variations in the scores of Latin America (60) and Europe (78). The index reflects the assertion that privatisation is much more attractive to prospective emulators than is the establishment of IRAs. The reason is simple: emulators make a political rather than a policy statement. Privatisation is a more assertive statement about a country's image and orientation than the creation of IRAs. The stronger propensity of privatisation for emulation does not mean that it is not a rational policy step but that it promises much higher rewards for emulators than the less glamorous job of designing IRAs.

The stronger propensity of public officials in strong states to delegate might be perceived by reference to the different levels of social support in weak and strong states. While the strength of the state increases with the social support it receives, social support also introduces checks to the arbitrary use of power. When officials' power is checked it is easier for them to grant more independence to regulatory authorities. Unlike the situation in strong states, power in weak states - to the degree that it is in the hands of public officials - is not constrained by societal pressure. As public officials' authority in weak states is more vulnerable, they are less likely to relinquish authority by delegating it to IRAs. ${ }^{19}$ This may also be the outcome of the stronger constraints on constructive action by politicians who aim to enhance state capacities. In a remarkable study on state capacities in Latin America, Geddes describes these constraints as the 'politician's dilemma', that is, the wrenching conflict between the politician's need for immediate political survival and longer-run collective interests in improving state capacities (Geddes, 1994: 18). While this dilemma is not unique to weak states, its effects in such states are much more troublesome. One direct implication is that by delegating power to independent regulatory authorities the politician deprives himself of a potential source of 
patronage and thus weakens his survival prospects. Thus, weaker social constraints on the extent of arbitrary use of power and stronger effects of patronage explain the greater propensity to emulation of transfers in weak states.

Public officials in strong and weak states differ in their vulnerability to coercive transfers and in their propensity to voluntary transfers. Weak states are prone to coercive transfers. The absolute levels of coercion and voluntarism are less significant than the variations across different states. While it may be reasonable to argue that transfers in both regions were voluntary (or coercive), it is quite clear that the context of reform in Latin America was less voluntary. The evidence for crisis-ridden decision-making is ample as is also of the pressure from international organisations, financial creditors and the United States. It is also clear that the levels of electrification and telephonication were lower in Latin America and thus represented a greater burden for public officials. As a final point, the Latin American utilities were more debt-ridden than the European and could hardly rely on subsidies from their national budget. Indeed, financial constraints had their effects in Europe, particularly for some of the countries opting to join the European Monetary Union (EMU). In these cases, the privatisation of public utilities was a mechanism that aided countries with budget deficits, like Italy, to qualify for membership of the EMU. Yet the scale of pressure in Europe was much lower than in Latin America. The VTI index captures some of the variations in the extent of coercion in the two regions as it summarises scores for the extent of partial privatisation and the differences in the timing of privatisation in the two sectors. Unlike Europe, the style of privatisation in Latin America was characterised by complete 'wholesale' privatisation, that is, the selling of a majority of, or more often all, the shares of the privatised company. The move was more gradual in Europe, in some cases merely selling a minority of shares, to that of selling a majority of shares in a time-span of around five years. In many cases, privatisation did not proceed beyond the threshold of a $50 \%+1$ share that were kept by the state. In other cases in Europe, golden shares were devised (especially in early privatisations) to ensure the protection of essential national and social interests not only by law and by the regulatory regime but also by preferential ownership rights. The time gaps between the privatisation of the two sectors were wider in Europe than in Latin America and again reflects the gradualism and discretion highly associated 
with voluntarism. It is thus rather unsurprising that Europe's score in the VTI index is higher than Latin America's.

Finally, public officials who have already opted for liberalisation may decide to prioritise simple or complex aspects of liberalisation. Our findings pointed to variations in the Complexity of Transfers Index across the Latin American and the European cases, with Europe scoring higher on complexity (145.5 points out of 192 compared with 60 for Latin America). One plausible explanation that links rational choice and institutional setting is that public officials in weak states will opt for simpler types of transfers due to their belief that simple transfers would be more likely to succeed in their institutional context. In doing so these public officials minimise costs of policy failure and reduce decision costs that represent a more severe burden on weak states. Yet, at the same time, they benefit from the rewards associated with 'liberalisation' as a learning process vis-à-vis both international creditors and domestic public opinion. Simpler forms of transfer mean that the extent of pressure on the incumbents and dependent constituencies (such as labour unions) are weaker and thus allow a diffusion of the opposition.

\section{Explaining Variations across both Nations and Sectors}

Why did European officials allow stronger variations than their counterparts in Latin America in the number and in the timing of privatisation events and in the establishment of SRAs and IRAs across sectors? This question is particularly engaging since sectors and nations are often perceived not only as competing levels of analysis but also as competing sources of authority. How come that the strong European states are less able to enforce a coherent and therefore similar pattern of governance across the two sectors? As decontextualised officials would behave similarly across nations and sectors, one has to seek variations in the context rather than in the motives of political action. .

The demand for and supply of social support varies across weak and strong states. Democratic regimes in Europe -- more stable than those of Latin America -- may also demonstrate a higher level of support for the state. This is evident not only from the general characteristics of these polities but also from the Europeans' greater emphasis on regulation for competition than on privatisation. It is particularly prevalent in 
electricity in five European countries where liberalisation allows small consumers to choose their electricity supplier. No Latin American country offers this option to consumers. Moreover, only one Latin American country has made an explicit commitment for future consumer choice, compared with four European countries. It is thus suggested that liberalisation is geared toward the maintenance and extension of social support in Europe and in strong states in general. When state preferences as to the governance of certain sectors diverge from the preferences of social groups the process of deliberation is likely to be more open in Europe than in Latin America. These deliberations shed light on the particularities of a sector and therefore modify the general outlines of liberalisation according to the sectors' special characteristics. Thus, one finds more cross-sectoral variations in Europe.

\section{Conclusions: Liberalisation and the Politics of Learning}

This paper set off with the question 'does politics determine learning or does learning determine politics?' This question is especially intriguing in light of the wide diffusion of liberalisation across nations and sectors. Thus we of necessity moved beyond the general indicators of privatisation (yes, no) and regulatory agencies (yes, no) to more perceptive indicators such as the measure of privatisation (partial, complete), the independence of regulatory agencies (independent or not), the timing of both and the patterns of regulatory reforms. In other words we shifted some of the discussion from whether liberalisation to how liberalisation. It is an especially intriguing case study because it serves for the argument that 'learning determines politics'. Not only is liberalisation widespread to the extent that it is beyond the reach (and interest) of any single actor in determining its course but (via the component of regulation-for-competition) it represents significant progress in the way public and private goals are accommodating each other.

The interaction between learning and politics in the diffusion of liberalisation was studied by combining insights and levels of analysis of the Policy Sector Approach (PSA) with that of the National Patterns Approach (NPA). The analytical framework presented in Table 1 allows us to aggregate cases and use descriptive statistics in order to detect similarities across sectors and nations, cross-sectoral variations, cross 
national variations and, finally, co-variations across sectors and nations. The four observations that were identified relate different but complementary stories on the advance of liberalisation. Each of these is essential in order to portray the broader picture of the diffusion of liberalisation and its interaction with learning.

The explanatory framework we employed here for the various patterns of liberalisation belongs to a research tradition that might best be termed 'actor-centred historical institutionalism'. Similarities across countries and sectors in the diffusion of liberalisation were discussed by pointing to the cost-benefit analysis of policymakers when the bandwagon of liberalisation started to move. Specifically it was argued that learning was induced by the benefits of emulation in a context of 'herding towards new convention'. New knowledge on the efficiency of liberal governance regimes cannot by itself bring change. It has to be diffused in a way that renders it politically beneficial to jump on the bandwagon and too politically costly to persist on sidelines. The explanation of cross-sectoral variations, namely, the greater propensity of telecoms for privatisation and the creation of SRAs and IRAs, had to move from methodological individualism toward a combination of actor-centred strategies and institutional analysis. Variations in the rewards and risks that the liberalisation of the two sectors represent for policy-makers explain the greater propensity of telecoms for liberalisation. Learning is thus mediated by cost-benefit analysis and the particular structure of incentives that each sector supplies.

Insights from the literature of historical institutionalism were found to be very useful when cross-national variations were considered. The findings that European states were receptive to learning, voluntary and complex patterns in the transfer of liberalisation, whereas the Latin American states were more receptive to emulative, coercive and simple transfers, were explained with reference to the variations in state formation in the two regions. Learning is mediated also by the capacity of the state to learn and thus strong states learn more than weaker states. This suggests that the creation of strong political and administrative institutions that will be able to promote economic development in Latin America is a much more complex task than suggested by neo-liberals that advocate deregulation. Finally, the greater support that the NPA received in Europe was explained by reference to the variations in the pattern of 
demand and supply for social support in weak and strong states. It is the weak demand for social support in the relatively weak Latin American states that explain the small variations between the Latin American group and the European one. This lead us to suggest that learning is directly connected to the extent of the demand for social support; and where social support is achieved through public deliberation of the costs and benefits of each option, the door is wide open for greater variations in the governance of different sectors.

By exploring the extensive role of regulation-for-competition in the advance of liberalisation, the paper sheds light on the fact that states (some more than others) gained rather than lost capacities with the restructuring of the governance structures in telecoms and electricity. Surely, liberalisation originated not in the state but in powerful interest groups, political visionaries, epistemic communities, international organisations and powerful governments. Their ability to transmit their ideas is highly impressive even in a world that is already defined as 'global' and 'interdependent'. But when the time was ripe for the idea to spread, states became critical agents both by mediating the process and, more importantly, by shaping its particular format by their capacities to learn. All in all, we portray the process of liberalisation as a new chapter in the ongoing tale of the state-building process that started in 15th century Europe. Fortunately for some, highly unfortunate for others, this tale kept its original outline when transmitted across continents and generations. Thus, those of us who thought that liberalisation and the so-called 'retreat of the state' might result in 'a new Europe' in Latin America are likely to be disappointed. Unfortunately, the ironic ring of the opening citation from Louis de Bernières' novel promises to live on in the future as it takes more than liberalisation and free markets to become 'European'. 


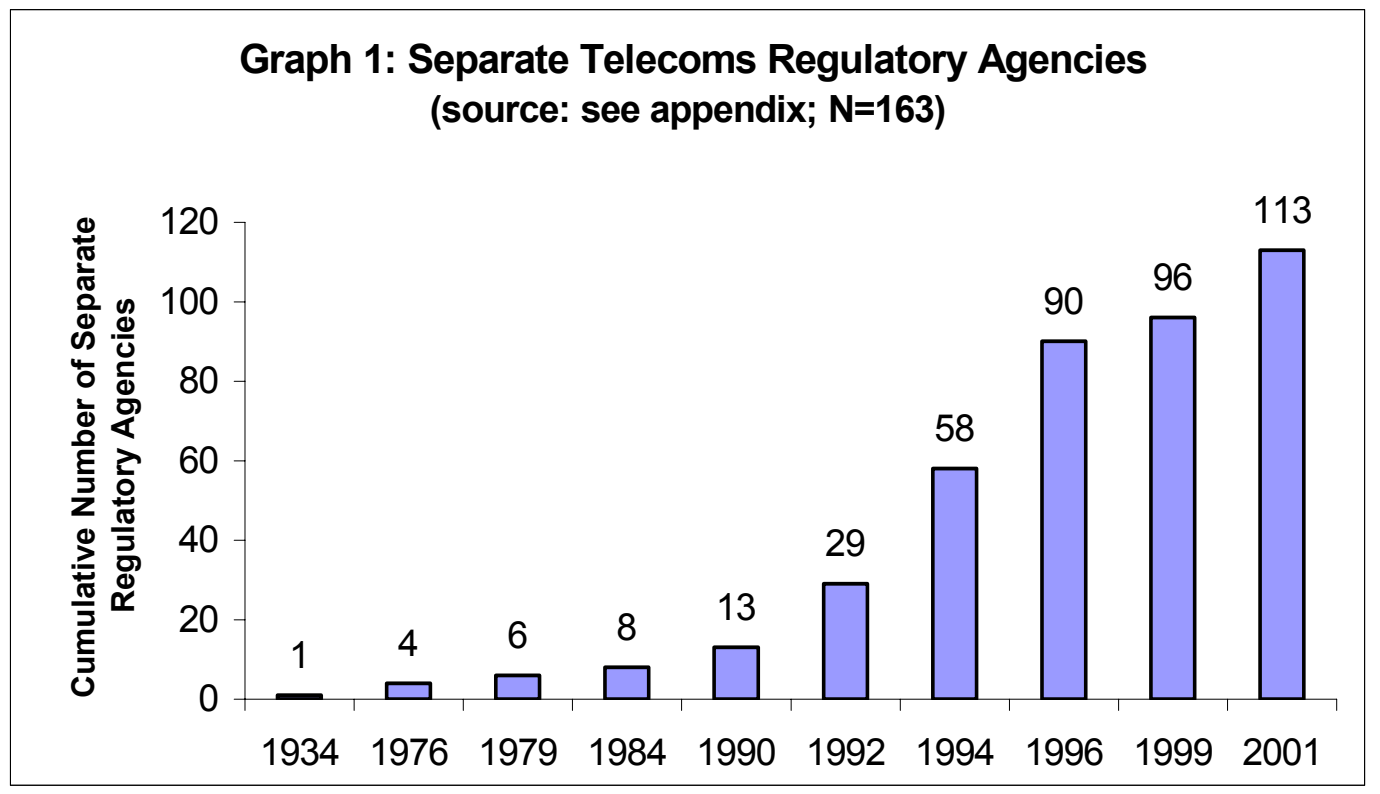




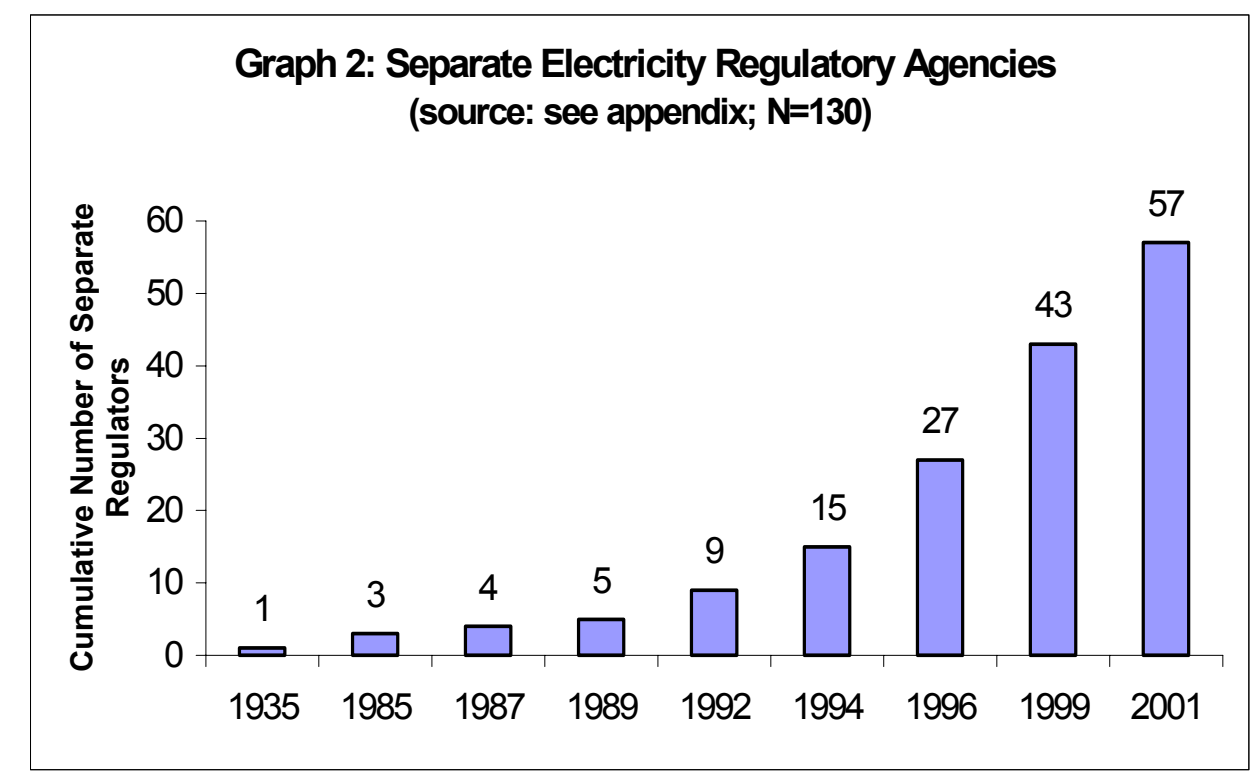

I.

\begin{tabular}{|c|c|c|}
\hline & $\begin{array}{c}\text { Cross-Sectoral } \\
\text { Similarities } \\
\end{array}$ & $\begin{array}{c}\text { Cross-Sectoral } \\
\text { Variations } \\
\end{array}$ \\
\hline $\begin{array}{c}\text { Cross- } \\
\text { National } \\
\text { Similarities }\end{array}$ & $\begin{array}{c}\text { Evidences do not } \\
\text { support either of the } \\
\text { two approaches. } \\
\text { Move to another level of } \\
\text { analysis }\end{array}$ & $\begin{array}{l}\text { Evidence support the } \\
\text { Policy Sector } \\
\text { Approach } \\
\text { (PSA) }\end{array}$ \\
\hline $\begin{array}{c}\text { Cross- } \\
\text { National } \\
\text { Variations }\end{array}$ & $\begin{array}{l}\text { Evidences support the } \\
\text { National Patterns } \\
\text { Approach } \\
\text { (NPA) }\end{array}$ & $\begin{array}{c}\text { Evidences support both } \\
\text { approaches } \\
\text { simultaneously. } \\
\text { Explore the conditions } \\
\text { in which one is more } \\
\text { acceptable than the } \\
\text { other }\end{array}$ \\
\hline
\end{tabular}

Table 1: Patterns of variations and similarities and their implications 
Table 2: Privatisation and Separate Regulatory Authorities (2000)

(Source see Appendix A)

\begin{tabular}{|c|c|c|c|c|c|c|c|c|c|}
\hline & \multicolumn{3}{|c|}{ All countries } & \multicolumn{3}{|c|}{ Latin American } & \multicolumn{3}{|c|}{ European } \\
\hline & $\begin{array}{c}{[1]} \\
\text { T\&E } \\
(N=64)\end{array}$ & $\begin{array}{c}{[2]} \\
\text { Tele } \\
(N=32)\end{array}$ & $\begin{array}{c}{[3]} \\
\text { Elec } \\
(N=32)\end{array}$ & $\begin{array}{c}{[4]} \\
\text { T\&E } \\
(N=32)\end{array}$ & $\begin{array}{c}5] \\
\text { Tele } \\
(N=16)\end{array}$ & $\begin{array}{c}{[6]} \\
\text { Elec } \\
(N=16)\end{array}$ & $\begin{array}{c}{[7]} \\
\text { T\&E } \\
(N=32)\end{array}$ & $\begin{array}{c}8] \\
\text { Tele } \\
(N=16)\end{array}$ & $\begin{array}{c}9] \\
\text { Elec } \\
(N=16)\end{array}$ \\
\hline $\begin{array}{l}\text { Privatisation } \\
\text { Events }\end{array}$ & $\begin{array}{c}44 \\
(N=63)\end{array}$ & 26 & $\begin{array}{c}32 \\
(N=15)\end{array}$ & 20 & 10 & 10 & 24 & 16 & $\begin{array}{c}8 \\
(N=15)\end{array}$ \\
\hline $\begin{array}{l}\text { Median Year } \\
\text { Privatisation } \\
\text { Events }\end{array}$ & $\begin{array}{c}1995 \\
(\mathbf{N}=\mathbf{6 3})\end{array}$ & 1996 & $\begin{array}{c}1995 \\
(\boldsymbol{N}=\mathbf{1 5})\end{array}$ & 1995 & 1994 & 1995 & 1996 & 1996 & $\begin{array}{c}1991 \\
(\boldsymbol{N}=\mathbf{1 5})\end{array}$ \\
\hline $\begin{array}{l}\text { Ownership } \\
\text { scores } 1975\end{array}$ & 1.5 & 1.2 & 1.8 & 1.3 & 1.1 & 1.6 & 1.7 & 1.3 & 2.1 \\
\hline $\begin{array}{l}\text { Ownership } \\
\text { scores 2000 }\end{array}$ & 3.1 & 3.4 & 2.8 & 3 & 3.2 & 2.9 & 3.2 & 3.6 & 2.7 \\
\hline $\begin{array}{l}\text { Regulatory } \\
\text { Agencies }\end{array}$ & 56 & 32 & 25 & 27 & 15 & 12 & 29 & 16 & 13 \\
\hline $\begin{array}{l}\text { Median Year } \\
\text { establishment } \\
\text { of Regulatory } \\
\text { Agencies }\end{array}$ & 1995 & 1995 & 1996 & 1995 & 1995 & 1994 & 1996 & 1993 & 1996 \\
\hline $\begin{array}{l}\text { Nominal } \\
\text { Independence } \\
\text { of Regulatory } \\
\text { Agencies }\end{array}$ & $\begin{array}{l}38 \mathrm{Yes} \\
18 \mathrm{No}\end{array}$ & $\begin{array}{l}21 \mathrm{Yes} \\
11 \mathrm{No}\end{array}$ & $\begin{array}{l}16 \text { Yes } \\
9 \text { No }\end{array}$ & $\begin{array}{l}13 \mathrm{Yes} \\
14 \mathrm{No}\end{array}$ & $\begin{array}{l}6 \text { Yes } \\
9 \text { No }\end{array}$ & $\begin{array}{l}7 \mathrm{Yes} \\
5 \mathrm{No}\end{array}$ & $\begin{array}{l}25 \mathrm{Yes} \\
4 \mathrm{No}\end{array}$ & $\begin{array}{l}15 \mathrm{Yes} \\
1 \mathrm{No}\end{array}$ & $\begin{array}{l}10 \mathrm{Yes} \\
3 \mathrm{No}\end{array}$ \\
\hline
\end{tabular}

Ownership Key: Private $=5$; 
Appendix A: The Internationalisation of Liberalisation

\begin{tabular}{|c|c|c|c|c|c|c|c|c|c|c|}
\hline \multirow[t]{3}{*}{ Country } & \multicolumn{5}{|l|}{ Telecom } & \multicolumn{5}{|l|}{ Electricity } \\
\hline & \multirow{2}{*}{$\begin{array}{c}\text { Privatisation } \\
\text { Year }\end{array}$} & \multicolumn{2}{|c|}{$\begin{array}{l}\text { Regulatory } \\
\text { Authority }\end{array}$} & \multicolumn{2}{|c|}{ Ownership } & \multirow{2}{*}{$\begin{array}{l}\text { Privatisation } \\
\text { Year }\end{array}$} & \multicolumn{2}{|c|}{$\begin{array}{c}\text { Regulatory } \\
\text { Authority }\end{array}$} & \multicolumn{2}{|c|}{ Ownership } \\
\hline & & Year & $\begin{array}{l}\text { Indepe } \\
\text {-ndent }\end{array}$ & 1975 & 2000 & & Year & $\begin{array}{l}\text { Indep- } \\
\text { ndent }\end{array}$ & 1975 & 2000 \\
\hline Argentina & 1990-1992 & $\begin{array}{l}1990- \\
1996 \\
\end{array}$ & No & $\begin{array}{l}\text { Mostly } \\
\text { Public }\end{array}$ & Private & 1992-98 & 1992 & Yes & Public & $\begin{array}{l}\text { Mostly } \\
\text { Private }\end{array}$ \\
\hline Austria & 1998 & 1998 & Yes & Public & Mixed & 1988 & None & NR & $\begin{array}{l}\text { Mostly } \\
\text { Public }\end{array}$ & Mixed \\
\hline Belgium & 1995 & 1993 & No & Public & Mixed & NRP & 2000 & Yes & Private & Private \\
\hline Bolivia & 1995 & 1995 & No & Public & Mixed & $1995-1997$ & 1994 & No & $\begin{array}{l}\text { Mostly } \\
\text { Public }\end{array}$ & $\begin{array}{l}\text { Mostly } \\
\text { Private }\end{array}$ \\
\hline Brazil & 1996 & 1997 & Yes & Public & $\begin{array}{l}\text { Mostly } \\
\text { Private }\end{array}$ & $1995-2000$ & 1996 & Yes & $\begin{array}{l}\text { Mostly } \\
\text { Public }\end{array}$ & $\begin{array}{l}\text { Mostly } \\
\text { Private }\end{array}$ \\
\hline Chile & $1982-90$ & 1982 & No & Public & Private & $1986-9$ & 1985 & No & Public & Private \\
\hline Colombia & None & 1995 & No & Public & $\begin{array}{l}\text { Mostly } \\
\text { Public }\end{array}$ & 1994-98 & 1994 & No & Public & $\begin{array}{l}\text { Mostly } \\
\text { Private }\end{array}$ \\
\hline Costa Rica & None & 1996 & Yes & Public & Public & None & None & NR & Public & Public \\
\hline Denmark & $1992-8$ & 1991 & Yes & Public & Private & None & 2000 & Yes & Mixed & Mixed \\
\hline Ecuador & None & 1995 & Yes & Public & Public & None & None & NR & Public & Public \\
\hline EI Salvador & 1997 & 1996 & Yes & Public & $\begin{array}{l}\text { Mostly } \\
\text { Private }\end{array}$ & 1998-1999 & 1996 & Yes & $\begin{array}{l}\text { Mostly } \\
\text { Public }\end{array}$ & $\begin{array}{l}\text { Mostly } \\
\text { Private }\end{array}$ \\
\hline Finland & 1998 & 1998 & Yes & $\begin{array}{l}\text { Mostly } \\
\text { Public }\end{array}$ & Mixed & None & 1995 & No & Mixed & Mixed \\
\hline France & 1997 & 1997 & Yes & Public & Mixed & None & 2000 & Yes & Public & Public \\
\hline Germany & 1996-00 & 1998 & Yes & Public & Mixed & $\begin{array}{c}1965, \\
1984-1990 \\
\end{array}$ & None & NR & $\begin{array}{l}\text { Mostly } \\
\text { Public }\end{array}$ & Mixed \\
\hline Greece & 1995 & $\begin{array}{l}1992- \\
\text { to-95 }\end{array}$ & $\begin{array}{l}\text { No-to- } \\
\text { Yes }\end{array}$ & Public & Mixed & None & 2000 & Yes & Public & Public \\
\hline Guatemala & 1997 & 1996 & No & Public & Private & 1997 & 1996 & Yes & $\begin{array}{l}\text { Mostly } \\
\text { Public }\end{array}$ & Mixed \\
\hline Ireland & $1996-9$ & 1997 & Yes & Public & Mixed & None & 1999 & Yes & Public & Public \\
\hline Italy & 1997 & 1998 & Yes & $\begin{array}{l}\text { Mostly } \\
\text { Public }\end{array}$ & Private & 1999 & 1996 & Yes & Public & $\begin{array}{l}\text { Mostly } \\
\text { Public }\end{array}$ \\
\hline Mexico & $1990-99$ & 1996 & No & $\begin{array}{l}\text { Mostly } \\
\text { Public }\end{array}$ & Private & None & 1994 & No & Public & Public \\
\hline Netherlands & 1994-00 & 1997 & Yes & Public & Mixed & 1999 & 1998 & Yes & $\begin{array}{l}\text { Mostly } \\
\text { Public }\end{array}$ & Mixed \\
\hline Nicaragua & None & 1995 & No & Public & Public & 2000 & $1992-7$ & $\mathrm{~N}-\mathrm{t}-\mathrm{Y}$ & $\begin{array}{l}\text { Mostly } \\
\text { Public }\end{array}$ & Mixed \\
\hline Norway & 2000 & 1987 & Yes & Public & Mixed & None & 1987 & No & $\begin{array}{l}\text { Mostly } \\
\text { Public }\end{array}$ & $\begin{array}{l}\text { Mostly } \\
\text { Public }\end{array}$ \\
\hline Panama & 1997 & 1996 & No & Public & Mixed & 1998 & 1997 & No & Public & $\begin{array}{l}\text { Mostly } \\
\text { Private }\end{array}$ \\
\hline Paraguay & None & 1996 & No & Public & Public & None & None & NR & Public & Public \\
\hline Peru & $1994-96$ & 1993 & Yes & Public & Private & 1993-1997 & 1997 & Yes & $\begin{array}{l}\text { Mostly } \\
\text { Public }\end{array}$ & $\begin{array}{l}\text { Mostly } \\
\text { Private } \\
\end{array}$ \\
\hline Portugal & 1995 & 1989 & Yes & Public & Private & $1997-2000$ & 1996 & Yes & Public & Mixed \\
\hline Spain & 1997 & 1996 & Yes & Mixed & Private & $1988-2000$ & 1994 & Yes & $\begin{array}{l}\text { Mostly } \\
\text { Private }\end{array}$ & $\begin{array}{l}\text { Mostly } \\
\text { Private }\end{array}$ \\
\hline Sweden & 2000 & 1992 & Yes & Public & Mixed & 1991,1996 & 1996 & Yes & $\begin{array}{l}\text { Mostly } \\
\text { Public }\end{array}$ & Mixed \\
\hline Switzerland & 1998 & 1992 & Yes & Public & Mixed & None & None & NR & $\begin{array}{l}\text { Mostly } \\
\text { Public }\end{array}$ & $\begin{array}{l}\text { Mostly } \\
\text { Public }\end{array}$ \\
\hline $\begin{array}{l}\text { United } \\
\text { Kingdom }\end{array}$ & $1981-93$ & 1984 & Yes & Public & Private & 1991-1995 & 1989 & Yes & Public & Private \\
\hline Uruguay & None & 2001 & Yes & Public & Public & None & 2001 & Yes & Public & Public \\
\hline Venezuela & 1991-96 & 1991 & No & Public & Private & None & 1992 & No & $\begin{array}{l}\text { Mostly } \\
\text { Public }\end{array}$ & $\begin{array}{l}\text { Mostly } \\
\text { Public }\end{array}$ \\
\hline
\end{tabular}


Appendix B: Patterns of Transfer

\begin{tabular}{|c|c|c|c|c|c|c|c|c|}
\hline \multirow[t]{2}{*}{ Country } & \multicolumn{2}{|c|}{$\begin{array}{c}\text { Privatisation } \\
\text { Style }\end{array}$} & \multicolumn{3}{|c|}{ Telecoms Competition } & \multicolumn{3}{|c|}{ Electricity Competition } \\
\hline & Telecoms & Electricity & $\begin{array}{l}\text { Competition } \\
\text { international } \\
\text { market }\end{array}$ & $\begin{array}{l}\text { Interco- } \\
\text { nnection } \\
\text { Rules }\end{array}$ & $\begin{array}{l}\text { Unbun- } \\
\text { dling } \\
\text { Local } \\
\text { Loop }\end{array}$ & $\begin{array}{l}\text { Vertical } \\
\text { Divestiture }\end{array}$ & $\begin{array}{l}\text { Open } \\
\text { Access } \\
\text { Trans- } \\
\text { mission }\end{array}$ & $\begin{array}{l}\text { Retail } \\
\text { Compe- } \\
\text { tition }\end{array}$ \\
\hline Argentina & $\mathrm{F}$ & $\mathrm{P}$ & $\mathrm{P}$ & Yes & No & Yes & RTPA & No \\
\hline Austria & $\mathrm{P}$ & $\mathrm{P}$ & Yes & Yes & Yes & Partial & RTPA & No \\
\hline Belgium & $\mathrm{P}$ & NRP & Yes & Yes & Yes & No & RTPA & No \\
\hline Bolivia & $\mathrm{F}$ & $\mathrm{F}$ & No & Yes & No & Yes & RTPA & No \\
\hline Brazil & $\mathrm{F}$ & $\mathrm{P}$ & $\mathrm{P}$ & Yes & No & Yes & RTPA & $\begin{array}{l}\text { No } \\
\text { P2005 }\end{array}$ \\
\hline Chile & $\mathrm{F}$ & $\mathrm{P}$ & Yes & Yes & No & Yes & RTPA & No \\
\hline Colombia & NP & $\mathrm{P}$ & Yes & Yes & No & YesP & RTPA & No \\
\hline Costa-Rica & NP & NP & No & No & No & No & No & No \\
\hline Denmark & $\mathrm{P}$ & NP & Yes & Yes & Yes & Partial & RTPA & $\begin{array}{l}\text { No } \\
\text { P2003 }\end{array}$ \\
\hline Ecuador & NP & NP & No & No & No & Yes & No & No \\
\hline $\begin{array}{l}\text { El } \\
\text { Salvador }\end{array}$ & $\mathrm{F}$ & $\mathrm{P}$ & Yes & Yes & Yes & Yes & NTPA & No \\
\hline Finland & $\mathrm{P}$ & $\mathbf{N P}$ & Yes & Yes & Yes & Yes & RTPA & Yes \\
\hline France & $\mathrm{P}$ & NP & Yes & Yes & Yes & Partial & RTPA & No \\
\hline Germany & $\mathrm{P}$ & $\mathrm{P}$ & Yes & Yes & Yes & Partial & NTPA & Yes \\
\hline Greece & $\mathrm{P}$ & NP & No & Yes & Yes & Partial & NTPA & No \\
\hline Guatemala & $\mathrm{F}$ & $\mathrm{P}$ & Yes & Yes & No & Yes & No & $\mathrm{No}$ \\
\hline Ireland & $\mathrm{P}$ & NP & Yes & Yes & Yes & Yes & RTPA & No \\
\hline Italy & $\mathrm{F}$ & $\mathrm{P}$ & Yes & Yes & Yes & Partial & RTPA & $\mathrm{No}$ \\
\hline Mexico & $\mathrm{F}$ & $\mathrm{P}$ & Yes & Yes & No & No & No & No \\
\hline $\begin{array}{l}\text { Nether- } \\
\text { lands }\end{array}$ & $P$ & $\mathrm{~F}$ & Yes & Yes & Yes & Yes & RTPA & $\begin{array}{l}\mathrm{N} \\
\mathrm{P} 2007\end{array}$ \\
\hline Nicaragua & NP & $\mathrm{P}$ & No & No & No & Yes & Yes & Yes \\
\hline Norway & $\mathrm{P}$ & NR & Yes & Yes & Yes & Yes & RTPA & Yes \\
\hline Panama & $\mathrm{P}$ & $\mathrm{F}$ & No & Yes & No & Yes & No & No \\
\hline Paraguay & NP & $\mathrm{NP}$ & Yes & None & None & No & No & No \\
\hline Peru & $\mathrm{F}$ & $\mathrm{F}$ & Yes & No & No & Yes & RTPA & No \\
\hline Portugal & $\mathrm{P}$ & $\mathrm{P}$ & Yes & Yes & Yes & Partial & NTPA & No \\
\hline Spain & $P$ & $P$ & Yes & Yes & Yes & Yes & NTPA & $\begin{array}{l}\text { No } \\
\text { P2007 }\end{array}$ \\
\hline Sweden & $\mathrm{P}$ & $\mathrm{P}$ & Yes & Yes & Yes & Yes & RTPA & Yes \\
\hline $\begin{array}{l}\text { Switzer- } \\
\text { land }\end{array}$ & $\mathrm{P}$ & NR & Yes & Yes & No & No & No & $\begin{array}{l}\text { No } \\
\text { P2008 }\end{array}$ \\
\hline $\begin{array}{l}\text { United } \\
\text { Kingdom } \\
\end{array}$ & $\mathrm{P}$ & $\mathrm{P}$ & Yes & Yes & Yes & Yes & RTPA & Yes \\
\hline Uruguay & NP & $N P$ & No & No & No & No & None & No \\
\hline$\underline{\text { Venezuela }}$ & $\mathrm{F}$ & NP & No & No & No & No & No & No \\
\hline
\end{tabular}

Key

F: Full. P: Partial. NP: No privatization, therefore not relevant.

PXXXX: Planned to year XXXX, RTPA-Regulated third party access.

NRTP: Negotiated third party access.

NR: Not relevant. 


\section{Notes for Appendix A:}

A privatisation event is documented when the some shares in the incumbent public operator(s) are transferred to private ownership. Ownership classifications for both sectors are based on my own estimate of the public share in the revenue of the industry. The classification was carried according to the following criteria: Mostly Public (more than 85\%), Mostly Public (70\%-85\%), Mixed (30\%-70\%), Mostly Private (15\%-30\%) and Private (less than 15\%). The ownership calculations in telecoms refer to the traditional business of telephony and not to the Internet or mobile markets. For regulatory authorities, the years refer to the start of operation, not to legislation. The classifications of independence of regulatory authority are nominal, that is, they refer to the role perceptions of the regulatory agency and the general statement by the legislators as to their intentions. But there are considerable variations in the degree of independence, which can be ignored only because the research design includes a relatively large number of cases.

\section{Sources for Appendix A and B and Graphs 1 and 2:}

Telecoms: Printed material for the telecom cases include:, Books by Noam (1992; 1998), Petrazzini (1995), Molano (1997) and Manzetti (1999) and paper by Wellenius (2000). In addition, interviews and e-mail exchanges with regulatory authorities and ministries were used such as EU regulatory developments (http://www.ispo.cec.be), the ITU regulatory database (http://www.itu.int/ITU-D-TREG/), the OECD (http://www.oecd.org/subject/regreform/ sectoral/telecommunications.htm) and World Bank Papers on Regulatory Reforms (http://econ.worldbank.org/topic.php?topic=14).

Electricity: Printed sources in the electricity cases include Pollitt (1997), Bacon (1999), Gilbert and Kahn (1996), several publications of the IEA (1996; 2001), and the Financial Times Energy (1995; 1997, 1998). Invaluable material was collected in the library of the International Institute of Energy Law, the University of Leiden. Interviews and e-mail exchanges with regulatory authorities and ministries. Online energy information of the US Department of Energy (http://www.eia.doe.gov/emeu/cabs/contents.html) as well as the Electricity Project of the Catholic University of Chile (http://www2.ing.puc.cl/power/) and the OECD (http://www.oecd.org/subject/regreform/sectoral/electricity.htm) and World Bank Papers on Regulatory Reforms (http://econ.worldbank.org/topic.php?topic=14) 


\section{Notes}

${ }^{1}$ Indeed, some of these notions were criticised as not political enough (that is, too accommodating to the learning-determine-politics approach; see, for example, Dolowitz, 2000: 3).

2 'So-called' because they are essentailly independent of the executive power but not of legislative oversight. Depending on various factors they are prone to 'business capture'. In some cases policy-makers establish Separate Regulatory Authorities (SRAs) but do not grant them independence. Thus one needs to distinguish SRAs from IRAs.

${ }^{3}$ Other notable developments in the 1980s were the opening of the end-user equipment market and the creation of an open environment for switching equipment and cellular telephony.

${ }^{4}$ In one case, that of electricity in Belgium, the system was practically fully privatised.

${ }^{5}$ Privatisation is defined here as the transfer of ownership rights from public to private hands. See Hodge (2000) for an extensive treatment.

${ }^{6}$ See Ragin, 2000; the small-N analysis web-site http://smalln.spri.ucl.ac.be/ and The Consortium on Qualitative Research Methods www.asu.edu/clas/polisci/cqrm/index.html

${ }^{7}$ These indicators reflect the quality of public service provision, the quality of bureaucracy, the competence of civil servants, the independence of civil service from political pressures, and the credibility of the government's commitment to policies.

${ }^{8}$ For a discussion of some of the issues( problems) associated with quantitative measurements of state strength see Migdal (1988: 279-286); Huber, Ragin and Stephens (1993); FauvelleAymar (1999).

${ }^{9}$ To some extent this problem affects not only EU member states but all other countries that are part of the 'global' economy. Globalisation strengthen the effects of interdependencies between observations and consequently lead to what is often called the Galton problem.

${ }^{10}$ The Commission does, however, use its influence to push countries in this direction. It is largely responsible for strengthening the independence of the Greek electricity regulator and it has tried to exert its influence over Germany, which opted not to establish an independent regulator at the federal level. The Commission's influence, however, seems to have been more effective in Eastern Europe than in EU member states.

${ }^{11}$ Given the spread of private investment since the 1980s in cellular phones, Internet and cables and in the supply of many of the new generation facilities, privatisation seems to be an even more powerful force than predicted by our statistics.

${ }^{12}$ Variations in the structure of ownership were observed only in telecoms, not electricity. In addition, the variation in the number of privatisation events seems limited (24 in Europe compared with 20 in Latin America).

${ }^{13}$ It is all the more so since cross-sectoral variations, at least as significant, were found though under a least-favourable research design. 
${ }^{14}$ The implementation of free-trade policies, for example, includes the reduction of tariffs, which is relatively easy for jurists and bureaucrats involved. As the European Commission found in the $1980 \mathrm{~s}$, it was much more difficult to proceed with the harmonisation of product standards that could act as effective obstacles to free trade.

15 'Convention' might be defined as a stable pattern of behaviour that is customary, expected and self-enforcing (cf. Young, 1996: 105).

${ }^{16}$ A counter-argument may suggest that it was possible to introduce new economic players to the generation segment and to enforce choice of electricity suppliers, at first to big consumers. Yet this strategy of gradualism could not be consensual in the same way that gradualism of telecoms was possible. Promoting choice for big consumers and reducing entry barriers for new electricity generation is a measure which promotes big business and thus cannot win the same level of consensus as the promotion of consumer choice in telecoms.

${ }^{17}$ The sum transferred to the electricity supply industry in California for competition purposes was about $\$ 7$ billion. In the Netherlands the bill is estimated to be $\$ 1$ billion.

${ }^{18}$ The primary energy sources for the generation of electricity.

${ }^{19}$ The emphasis here is on likelihood terms only because, despite the different institutional constraints in weak and strong states, public officials across both types of states have to respond positively to the new common wisdom on the benefits of IRAs as well as to pressures of international institutions.

\section{Bibliography}

Anglade Christina and Fortin Carlos, (1985). The State and Capital Accumulation in Latin America, Macmillan, London.

Atkinson M. Michael and Coleman D. William, (1989). "Strong States and Weak States: Sectorial Policy Networks in Advanced Capitalist Economies", British Journal of Political Science, Vol. 19, pp. 47-67.

Bacon, Robert (1999), A Scorecard for Energy Reform in Developing Countries, The World Bank, Washington.

Bennet, J. Colin, (1991). "What is Policy Convergence and What Causes It?", British Journal of Political Science, Vol. 21, pp. 215-233.

Bennet, J. Colin (1991) "How States Utilize Foreign Evidence”, Journal of Public Policy, Vol. 11, No. 1, pp. 31-54.

Bikhchandani Sushil, Hirshleifer David and Welch Ivo, (1992). "A Theory of Fads, Fashion, Custom, and Cultural Change as Informational Cascades”, Journal of Political Economy, Vol. 100, pp. 992-1026.

Cardoso, Frenando H. and Faletto, Enzo, (1979). Dependency and Development in Latin America, University of California Press, Berkeley. 
Cukierman Alex, (1992). Central Bank Strategy, Credibility, and Independence: Theory and Evidence, MIT Press, Cambridge, Mass.

DiMaggio Paul and Powell Walter (1991). "The Iron Cage Revisited: Institutional Isomorphism and Collective Rationality in Organizational Fields, In: DiMaggio Paul and Powell Walter (eds). The New Institutionalism in Organizational Analysis, The University of Chicago Press, Chicago and London, pp. 63-81.

Dolowitz David (2000). "Introduction (for special issue on Policy Transfer), Governance, Vol. 13, pp. 1-4.

Dolowitz David and Marsh David, (2000). "Learning from Abroad: The Role of Policy Transfer in Contemporary Policy Making" Governance, Vol. 13, No. 1, pp. 524.

Doren G. Bruce and Wilks Stephen (eds). (1998). Changing Regulatory Institutions in Britain and North America, University of Toronto Press, Toronto

Fauvelle-Aymar Christine, (1999). "The Political and Tax Capacity of Government in Developing Countries", Kyklos, Vol. 52, pp. 391-413.

Financial Times Energy, (1995). Electricity Generation in Latin America : Sector Reform and Privatisation, FT, London.

Financial Times Energy, (1997). Electricity in Europe: Into the Single Market, FT, London, Two Volumes.

Financial Times Energy, (1998). Electricity and Gas Regulation in Latin America, FT, London.

Fishlow, Albert, (1990). 'The Latin American State', Journal of Economic Perspectives, Vol. 4 (3). pp. 61-74.

Geddes, Barbara, (1994). Politician's Dilemma : Building State Capacity in Latin America, University of California Press, Berkeley.

Gilbert Richard and Kahn Edward (1996). International Comparisons of Electricity Regulation, University of Cambridge Press, Cambridge.

Granovetter Mark, (1978). "Threshold Models of Collective Behavior", American Journal of Sociology, Vol. 83, pp. 1420-1443.

Haas M. Peter, (1992). "Introduction: Epistemic Communities and International Policy Coordination”, International Organization, Vol. 46, No. 1, pp. 1-36.

Hall, Peter, (1989). The Political Power of Economic Ideas : Keynesianism across Nations, Princeton University Press, Princeton. 
Hall Peter and Taylor C.R. Rosemary, (1996). 'Political Science and the Three New Institutionalisms”, Political Studies, Vol. 44, pp. 936-957.

Hemerijck, Anton and van Kersbergen Kees, (1999). "Negotiated Policy Change: Towards a Theory of Institutional Learning in Tightly Coupled Welfare States", In: and Braun Dietmar and Busch Andreas, Public Policy and Political Ideas, Edward Elgar, Cheltenham, pp. 168-185.

Henry Claude and Matheu Michel, (2001). "New Regulation for Public Services in Competition", In: Henry Claude, Matheu Michel and Jeunemaitre Alain (eds), Regulation of Network Utilities; The European Experience, Oxford University Press, 2001, pp. 1-35.

Hodge A. Graeme, (2000). Privatisation; An International Review of Performance, Westview Press, Boulder, Colorado.

Hollingsworth J. Rogers, Schmitter C. Philippe and Streeck Wolfgang, (1994). "Capitalism, Sectors, Institutions and Performance", in: Hollingsworth et al., (eds.). Governing Capitalist Economies, Oxford University Press, New York and Oxford, pp. 3-16.

Huber Evelyne, Ragin Charles and Stephens D. John, (1993). "Social Democracy, Christian Democracy, Constitutional Structure, and the Welfare State", American Journal of Sociology, Vol. 99, No. 3, pp. 711-749.

Huntington, Samuel, (1968). Political Order in Changing Societies, London, Yale University Press.

IEA, (1996). The Role of IEA Governments in Energy, International Energy Agency, Organization for Economic Co-operation and Development, Paris.

IEA, (2001). Competition in Electricity Markets, International Energy Agency, Paris.

Ikenberry G. John, (1990). "The International Spread of Privatisation Polices: Inducements, Learning, and "Policy Bandwagoning", In: Suleiman Ezra and Waterbury John, The Political Economy of Public Sector Reform and Privatisation, Westview Press, Boulder, pp. 88-110.

Kaufmann, Daniel, Aart Kraay and Pablo Zoido-Lobaton (1999a). Aggregating Governance Indicators, World Bank Policy Research Department Working Paper No. 2195 .

Kaufmann, Daniel, Aart Kraay and Pablo Zoido-Lobaton (1999b). Governance Matters. World Bank Policy Research Department Working Paper No. 2196.

Kalyvas Stathis, (1994). 'Hegemony Breakdown: The Collapse of Nationalisation in Britain and France', Politics and Society, Vol 22, No. 3, pp. 316-348. 
Levi, Margaret (1988). On Rule and Revenue, University of California Press, Berkeley.

Levi-Faur, David (1998). "The Competition State as a Neo-Mercantilist State", The Journal of Socio-Economics, Vol. 27 No. 6, pp. 665-685.

Levi-Faur, David (1999). 'The Governance of Competition: the interplay of technology, economics, and politics in the making of the European Union's electricity and telecoms regimes", Journal of Public Policy, Vol. 19, No.2, pp. 137-169.

Levi-Faur, David (2000). "The Rise of the Competition State: Regulatory Reforms in the UK and the US", Current Politics and Economic in Europe, Vol. 9, No. 4, 2000, pp. 427-455.

Levi-Faur, David (2002a). "Herding towards a New Convention: On herds, shepherds and lost sheep in the liberalisation of the telecommunications and electricity industries", Nuffield College Working Papers in Politics, No 6.

Levi-Faur, David (2002b). 'On the "Net Impact" of the European Union Policy Process: The EU's telecoms and electricity Regimes between the global and the national', European Integration Online Papers, Vol. 6, http://eiop.or.at/eiop/.

Levy Brain and Spiller Pablo (1996). Regulations, Institutions, and Commitment; Comparative Studies of Telecommunications, Cambridge University Press, Cambridge.

Lewis M. Colin, (2001). State, Market and Economic Policy: Government and the Private Sector in Latin America, Unpublished Manuscript.

Majone Giandomenico, (1990). Deregulation or re-regulation?: Regulatory Reform in Europe and the United States, London: Pinter.

Majone Giandomenico, (1991). Cross-National Sources of Regulatory Policy Making in Europe and the United States, Journal of Public Policy, Vol. 11, No. 1, pp. 79-106.

Manzetti, Luigi, (1999). Privatisation South American Style, Oxford University Press.

Migdal Joel, (1988). Strong Societies and Weak States: State-Society Relations and State Capabilities in the Third World, Princeton: Princeton University Press.

Molano Walter, (1997). The Logic of Privatisation: The Case of Telecommunications in the Southern Cone of Latin America, Westport, Conn. ; London : Greenwood Press,

Moran Michael, (2001). 'The Rise of the Regulatory State in Britain', Parliamentary Affairs, Vol. 54, No. 1, pp. 19-34.

Müller M Markus., (2002). The New Regulatory State in Germany, Birmingham: Birmingham University Press. 
Natalicchi Giorgio, (2001). Wiring Europe: Reshaping the European

Telecommunications Regime, Lanham, Boulder: Rowman \& Littlefield Publishers.

Newbery M. David, (1999). Privatisation, Restructuring, and Regulation of Networks Utilities, Cambridge, Mass.: The MIT Press.

Noam, Eli (1992). Telecommunications in Europe, Oxford University Press, New York.

Noam Eli, (1998). Telecommunications in Latin America, New York, Oxford University Press.

Nordlinger A. Eric, (1981). On the Autonomy of the Democratic State .Harvard University Press, Cambridge, MA.

Nordlinger A. Eric, (1987). "Taking the State Seriously", In: Weiner Myron Huntington P. Samuel (eds.). Understanding Political Development, Little \& Brown, Boston, pp. 353-390.

Petrazzini, Ben, (1995). The Political Economy of Telecommunications Reform in Developing Countries: Privatisation and Liberalisation in Comparative Perspective, Westport, Conn ; London : Praeger.

Pollitt G. Michael, (1997). "The Impact of Liberalisation on the Performance of the Electricity Supply Industry: An International Survey", The Journal of Economic Literature, Vol. 3, pp. 3-31.

Pool, Ethel de Sola (1983) Technologies of Freedom. Cambridge, Mass.: Balkan Press.

Przeworski, Adam and Teune Henry, (1970). The Logic of Comparative Social Inquiry, Wiley-Interscience, New York.

Ragin C. Charles, (2000). Fuzzy Set Social Science, Chicago: The University of Chicago Press.

Richardson Jeremy (ed.). (1982). Policy Styles in Western Europe, George Allen \& Unwin, London.

Rogers M. Everett (1983). Diffusion of Innovations, The Free Press, New York, $3^{\text {rd }}$ edition.

Rokkan, Stein (1975). "Dimensions of State Formation and Nation-Building: A Possible Paradigm for Research on Variations within Europe", in C. Tilly, The Formation of National States in Western Europe, p. 600.

Rose, Richard (1991). “What is Lesson-Drawing?”, Journal of Public Policy, Vol. 11, No. 1, pp. 3-30. 
Sabatier Paul and Jenkins-Smith Hank (eds) (1988). Special Issue: Policy change and Policy-Oriented Learning: Exploring an Advocacy Coalition Framework, Policy Science, Vol. 21, No. 2/3, pp. 123-277.

Scharpf, Fritz (1997). Games Real Actors Plays: Actor Centred Institutionalism in Policy Research, Westview Press, Boulder.

Schmidt, Susanne K., (1997). 'Sterile Debates and Dubious Generalisations: European Integration Theory Tested by Telecommunications and Electricity'. Journal of Public Policy, 16, 233-271.

Thelen Kathleen and Steinmo Sven, (1992). "Historical Institutionalism in Comparative Politics", in: Steinmo Sven, Thelen Kathleen and Longstreth Frank (eds.). Structuring Politics; Historical Institutionalism in Comparative Analysis, Cambridge University Press, pp. 1-32.

Tilly Charles, (1975). The Formation of national states in Western Europe Princeton : Princeton University Press.

Veljanovksi, C. (1987). Selling the State, London: Weidenfeld and Nicolson.

Vickers, J. and Yarrow, G. (1988). Privatisation: An Economic Analysis, London: MIT Press.

Vogel David, (1986). National Styles of Regulation: Environmental Policy in Great Britain and the United States, Cornell University Press, Ithaca and London.

Vogel, Stephen K. (1996). Freer Markets, More Rules: Regulatory Reform in Advanced Industrial Countries, Cornell University Press, Ithaca and London.

Waarden van Frans, (1995). "Persistence of National Policy Styles: A Study of Their Institutional Foundations", in: Unger Brigitte and Waarden van Frans, Convergence or Diversity?, Avebury, Aldershot, USA, pp. 333-372.

Wellenius, Bjorn, (2000). 'Regulating the Telecommunications Sector: The Experience of Latin America', In: Manzetti Luigi, Regulatory policy in Latin America: Post-Privatisation Realities, Coral Gables, Fla. : North-South Center Press, pp. 189-241.

Young Peyton H. (1996). "The Economics of Convention", Journal of Economic Perspective, Vol. 10, pp. 105-122.

Whitehead, Laurence, (1994). 'State Organization in Latin America Since 1930, In: Bethell Leslie' The Cambridge History of Latin America, Vol. VI, Cambridge, Cambridge University Press, pp. 3-95. 